\title{
Targeting Communicative Competence Through Poetry as a Tool
}

\author{
P. Deepa, M. Ilankumaran
}

\begin{abstract}
Communication is the process of establishing a connection between two points of information exchange. It is essential to everyone for giving and receiving information when they communicate their ideas. Communication skills are necessary for the development of self-advocacy and selfdetermination. It is one of the essential components of the foundation of the personality. The role of literature and the source of authentic texts of the language curriculum have been gaining in recent years. There has been a hot debate among language learners as to how, when, where, and why literature should be incorporated in the ESL curriculum. Reasons for using literary texts in second language classroom and main criteria for selecting suitable literary texts in second language classes are stressed so as to make the reader familiar with the underlying reasons and criteria for language teachers' using and selecting literary texts. Learning poetry is extremely helpful for a learner to grasp the rhythmic aspect of the language. Poetry serves not only a model of literature but also a model for teaching skills of language such as reading and writing. Poetry is an effective way of language teaching. The student can easily relate structures and themes with the help of poetry. Moreover, it promotes the students to learn new words and different literary terms. This paper focuses on how communication skills can be improved through listening to poetry. Learning literature provides a platform to improve student's communication skills. When the students read poetry, it improves their vocabulary, sentence, syntax, fluency and the creative skills. Teaching poetry is also interesting as far as teacher's point of view is concerned. Learning poetry helps the students to enhance their fluency.

Keywords: Language, Communication, Literature, Poetry, Pronunciation, Speaking Skills.
\end{abstract}

\section{INTRODUCTION}

Communication is the way to vent of one's images of mind and experience gained. English in India is generally taught as the second language. Literature in its broadest sense could be the record of the best thoughts of the best minds. The learning level of the students increases on the basis of the techniques used by the teachers in the language classroom. Techniques play a key role in language teaching. Communicative activities comprise several methods that inspire and demand a student to speak out and listen to others including the participants in the activity. Literature is an interesting subject, which reflects life of all. Literature can be expressed with the help of language. The entire literature is constructed by the language in which it is written. It has completely encompassed the life, since the birth to death. Poetry is an important genre that gives delight to the readers. The researcher has taken poetry, as a potential tool for the enhancement of speaking skills.

Revised Manuscript Received on July 10, 2019.

P. Deepa, Assistant Professor of English, Noorul Islam Centre for Higher Education, Kumaracoil, T.N, India. (e-mail: deepam_nice@rediffmail.com)

M. Ilankumaran, Professor of English, Noorul Islam Centre for Higher Education, Kumaracoil, Thuckalay, Tamilnadu, India.

(e-mail: mikumaran@yahoo.com)

\section{SPEAKING SKILLS}

The spoken language is much more frequently employed in communication than in the written language. People invariably learn to speak before they learn to write. Extra verbal factors, gestures, facial expressions, mannerisms, vocal qualities and physical hearing play a prominent role. People understand each other better when they meet face to face. Speaking skills play a key role in the entire field. It is an important attribute that highlights one's personality. Language is a medium of communication; it benefits all aspects of life from the professional to social one. It can be often obstructed by a series of factors, such as shyness, lack of self-confidence, laziness and so on. Implementing language skills in the classroom helps the language learners to develop their ability in using four skills. Speaking is one of the most prominent language skills. People have used speaking rather than writing. While participating in classroom activities teachers have to help the learners to build their trust and confidence at the time of speaking. Communication is the basis of effective L2 learners. To attain the targeted efficiency in second language, the learners and teachers have to combine themselves interestingly in the process.

\section{COMMUNICATIVE COMPETENCE}

Speaking is a predominant part of language learning. Teachers have to coach the students by giving dialogues from the prescribed text. However, the main aim of the teacher is to enhance the speaking ability of the students. So, that the students can learn to follow the cultural and social rules in their communicative circumstances. In order to speak the language better, the teacher has to give some activities for the students. Few of the activities are as follows:
a. Communicative Speaking Activities
b. Working on Pronunciation
c. Writing activity
d. Some pros and cons

\section{TEACHING LITERATURE}

The goal of the teacher is to enhance the language skills of the students by teaching poetry in a language classroom. The concentration of the students towards learning the language is making a person master the language. Literature is an authentic tool to enhance speaking skills. The teacher has to use some techniques to teach the spoken language. Teaching speaking skills through stories is effective and also it is interactive.

Published By:

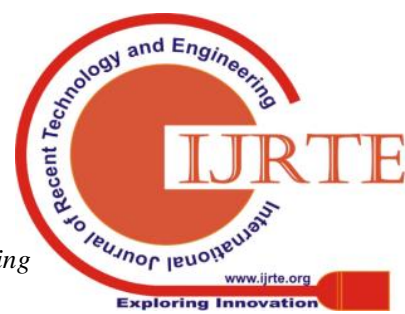


Listening the stories in the poem enrich the visual imagination and creativity. Stories can organize, retain and assist students to access information. When students are taught speaking skills through story based activities, it not only improves their active and passive vocabulary but also it can focus on stress, intonation, pronunciation, pause and articulation of voice. Literature is a treasure world of books and authors. Like a vast sky, it has no boundaries and end. In this beautiful garden, fresh and new flowers bloom every day without fading and provide wisdom to all. Literature can provide both wisdom and pleasure to the readers.

The world is a globalized one, there is a great scope for people who have developed their speaking activity well and can communicative effectively and efficiently. The rural area students are really poor in speaking English. This has happened because of improper listening, inattentiveness in the classroom, showing lack of interest, poor vocabulary and weak motivation. After the proper advice and exercise given by the teacher, positive results have been witnessed among the students.

Few rural area students find difficult of grasping the language, because they feel as if they have inferiority complex. This type of complex has to be avoided and the learners need to feel free to express the views and suggestions. More number of opportunities can be given for the upliftment of students' career. A Teacher has to stimulate the second language learners to observe experiment, discover and learn in comfortable surroundings. By giving more number of practices to the students, the Tamil students can also speak better English. Errors are a necessary evil because students learn through committing errors and so they should not be insulted or disrespected but analyzed and interpreted.

The major reason for language competence is the students are economically deprived learners so, they do not have enough time for proper interaction to enrich their competency or fluency and to have the proper vocabulary practice and command over the language as they do part time work to help their parents financially. Hardly, they enjoy reading newspapers, magazines, books and literary articles and televisions etc., which provide them with adequate experiences for the development of communicative skills. From the improvement of vocabulary among the students, the teacher has to spend at least the last ten minutes in a period for vocabulary building beyond the syllabus. The students have to note the words immediately after the teacher has completed the poem. They have to understand the context also. An English teacher should use creative techniques to imbibe new words with interactive activities. An academic record is not at all enough for getting employment. Good communication and basic writing skills are needed for the students to shine better in career. In rural side, the students make difficult of framing sentences in English. A language trainer has to create songs with the words. By singing them, students will acquire new words so easily.

\section{LITERATURE AS A TOOL IN TEACHING LANGUAGE}

The main target of the English teacher is to create an inevitable enthusiasm among students to learn new words. A teacher's motivation and student-friendly teaching enable vocabulary learning more effective. An English teacher induces the taste in reading poems, short stories, etc. The students have to select poems and stories according to their taste. If they become accustomed to read, they automatically start reading bulky stories and literature. Teacher has the caliber to imbibe the art of using right and exact word at the right time. He/She should insist the students to use perfect and exact words at the right time. Students have to use idioms, phrases, figurative speeches at the time of speaking.

Students should always be encouraged to attend workshop and ask them to implement new ideas. This helps them to enhance their knowledge and speak with more confidence. The students need to read the poem several times, only after that they have to come to the conclusion. Poetry is the genre which helps the listener to completely involve into them. They can share their ideas, views, opinions in order to establish themselves. Literature is the reflection of life. Whatever happened in the life can be reflected in literature. Students can read several things in poetry. All can be incorporated in their day to day life. Activities, strategies, approaches, methods and procedures have to be implemented in the classroom for teaching objective. The talent of the students has also been increased through listening to the language classroom. Poems are easily comprehensible and meaningful to the learners. Their educational and social background should be considered. It exerts to highlight the linguistic skills of the learners helping in exploiting the different ways of expressions.

Literature is a tool to learn different ideas about different authors. Any sort of task can be given to impart the ability of the student's language skills. Learning poetry makes the students reflect their caliber in the language. The teacher has to give maximum time to recollect the previous class portion before starting the new topic. English teachers need to be the passive listeners in the class, which does not mean that they loss control, but a sign of belief that students learn by using language for purposeful communication. The innovative methods of poetry make the learners think in an imaginative way. It creates different perceptions in the mind of the readers. As poetry is an interesting genre, it gives flavor to language and pleasure to the readers too. It tempts the reader to think, create, imagine in different ways.

The students have to get adequate confidence in the public and to take participation in all activities regarding communication. The students who are expert in language skills can definitely be talented in other three skills too. Only through practice, they can survive without fear or hesitation. As practice makes the man perfect, the speaking of a language can be developed in a perfect manner only through rigorous practice. As far as poetry is concerned, when the teacher teaches poetry in the classroom, the student's language proficiency, their interest towards literature can be taken into account with appropriate materials. Poetry gives ideas to learn more new words at the same time; it can be used in day to day life activities to develop the communication skills.

It is a pertinent choice among all other genres of literature to make students involve and 
enrich in the communication process and to propel them to speak the language in an effective manner.

The above points prove that poetry helps to enhance the language skills of the students. First and foremost thing is that, the teacher can choose an apt language which is understandable for the students. Teacher has to create the poetic atmosphere and environment for teaching poems. Students can gain more knowledge and they can internalize the language at a high level.

Effective conversation and discussion skills in English are mandatory for the development of a profession. To succeed both in academics as well as in employability skills, the students should participate in group discussion and conversations regularly and discuss the subjects they learn besides the day to day happenings in the society. Daily conversations and discussion assist the learners to enhance spoken skills. Students are able to learn, understand and express cause and effect during the conversation and discussions from the texts they everyday lives. The students can be allowed to converse or discuss classroom lectures, examination patterns, action plans, use of language and details of vocabulary, democratic participation across roles and responsibilities. The students also find several ideas to discuss and there is a possibility to get various options or suggestions and freedom to choose. It is clear that the learning is lifelong, life wide and life deep.

Poetry can be the works of great beauty due to its meter and rhyme scheme like the ebb and flow of an ocean. This really helps the students to show more involvement towards poetry. On the other hand, the students can try to know more vocabulary from the lines of the poems. Through different terms of poetry used in the classroom, the students get benefits of knowing new terms and works.

\section{TEACHING OF POETRY IN LANGUAGE CLASSROOM}

Poetry is a thing of beauty, beauty of form, beauty of language, beauty of thought and mood or feeling. It can serve as a catalyst in developing language skills. According to Thomas Hardy, "Poetry is emotion put into measure. The emotion must come by nature, but the measure can be acquired by art". It is an imaginative response to an experience reflecting a keen awareness of language. The role of the teacher is a facilitator to develop the richness of poetry. Some of the poetic aspects are:
a) Idea and emotion
b) Type and Form
c) Style of the line
d) Concise word choice

A few students understand the poem taught comparatively quicker as they grasp matters even while teaching. On the contrary, few felt difficult in understanding the concept of poetry. Such type of student's ability can be improved only by giving more practice. The teacher can split the students depends upon their talent in three different catagories. They are average, below average and above average. Work can be distributed to these three catagories of students. For each student, 10 to 15 minutes can be given depending upon the students presentation. The teacher has to motivate them by extending the time duration. The teacher can conduct few activities for the students to enhance the ability of the language of second year students. These activities not only give enjoyment but also it helps to know new vocabulary.

Poetry is a tool with which the students can achieve their target. Speaking practice can be given to them for getting more confidence. Motivation of the teacher is important to the enhancement of the students. The questions can be asked by the teacher that would develop the refinement in the taste of the students. These questions should be helpful in bringing about the feelings and emotions of the poet. As a result, they face the spectators without any tension. Poetic words can be always used when they are communicative with others. Thus, teaching poetry as a genre in the classroom makes the students think innovatively and become confident speakers in the society. In every class, the role of teacher's is also indispensible; they have to pre-plan about the way how the poem can be conducted before entering the classroom.

Poetry has its own structures, purposes, languages and general characteristics. The reader has to analyze poetry from poetic devices, types, sound devices, structural devices and all aspects. It makes the students feel intense, experience deeply and helps the students to interpret their own ideas and views.

\section{TEACHING ACTIVITIES IN CLASSROOM}

Teaching of English is quite different from that of any other subject in arts, science and commerce. It has to be done consciously and meticulously. The teacher can improve the language skills of the students through different activities. Moreover, students have to be motivated to show a lot of interest to participate in the activities. Many activities are useful to enhance the caliber of the students. The following are some of the activities. They are;

\section{Role Play}

Role Play is a drama like activity in which the students take different roles in a typical situation. This activity is used to give learners practice in using language in different situations. The teacher has to provide such opportunities of role playing to the students and encourage them to speak naturally. There may be role play between two or more students. Students take immense pleasure while involving into role play. For example, Nissim Ezekiel's Poem Good bye party to Miss. Pushpa. Teacher defines the character from the poem and asks them to perform on the stage. This activity is beneficial to the students for improving their vocabulary.

\section{Story Telling}

The second technique used in the classroom is story telling. It is the social and cultural activity of sharing stories, often with improvisation, theatrics or embellishment.

Telling stories is a fun for the teachers as well as the students. By explaining stories, the imaginative and the memory power of students can be improved. The poem The Bailiffs daughter of Islington written by an anonymous writer is about the love between squire's son and

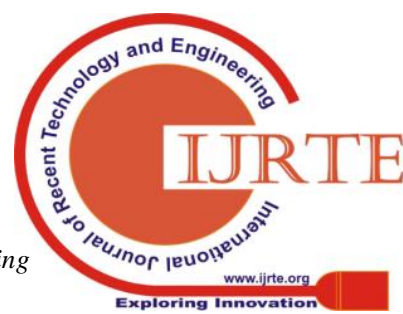


Bailiff's daughter. The teacher has to present the poem and ask the students to explain the story. The creative power of the students also gets enhanced along with language proficiency. The students can reproduce the sentences from memory. Such techniques help them to improve their memory power.

\section{Narration}

Narrating incidents can do favour in improving the speaking ability of the students. Any incidents or events can be taken from the poem. For eg; Shakespeare's 'Shall I Compare thee to Summer Day?', the theme of the poem is love. The students can be asked to narrate the theme love. Narration should be in such a way that the listeners should feel that they are experiencing the incidents in reality. The incidents of the students are from their own experience, the oral expressions of the students become flawless and clear. The teacher should supervise that the other students are listening to the narration of incidents while a student is doing that. If the students listen to the story keenly, it will definitely help them to understand the comprehension quickly. Moreover, there should be a complete freedom for the students to narrate any incidents. This activity makes the students speak freely without hesitation.

\section{Extempore}

The extempore can be conducted in the classroom to test the student's English capability. No doubt that students show more interest to participate in extempore. This type of competition brings great scope for the students to enhance their speaking competency. Such techniques help the students to measure the depth of knowledge rather than their resourcefulness and eloquence. In order to make the students well versed in speaking and thus great orators, the teachers have to provide adequate practice. The advantages to participate such extempore are to speak before of the audience. The teacher has to assign the easiest topic at the beginning and encourage the students to participate. This technique improves their skill of eloquence as well as vocabulary.

\section{Debate}

Debate is still prescribed in many schools and colleges. It is the most useful activity for the enhancement of the language skills of the students. It is a formal discussion in a public meeting in which opposing arguments are put forward. It promotes the fluency and helps the students to get rid of the shyness. Debates can be a one-stop formula to succeed at almost everything. Examples can be given from the poem Robert Frost's Mending Wall and Road not taken. Students can argue with the themes and conclude with one theme. This really supports the students to speak and think in different dimensions.

Teaching of English has now become all the more challenging in this internet era in which too much of knowledge more than what the learners really need for their young age is thrust upon them. From these activities it is very clear, how the language teachers manage to direct the learners towards these twin goals of not only making the learners acquire the proficiency in the language, but also imbibe the values of life. The researcher has chosen three domiciles that are Urban, Rural and Semi Urban. The objective of the researcher is to improve the communication skills of the rural area because the family background of the students looks poor. The motto of the researcher is to enrich the speaking skills of the students by giving more training and practice.

\section{TECHNIQUES TO TEACH POETRY}

Poetry is an interesting area in which everyone is impressed because of the melody. The writing style of the poem is also different from other genres in literature. It paves way for the learning and teaching of basic language skills. Poetry uses forms and conventions to suggest interpretation to words or to evoke emotive responses Poetry is an innovative method for language teaching and makes students familiar with figures of speech such as metaphor, simile, oxymoron, paradox etc., in their daily communication. They have to practice in such a manner that the communication skills can be developed. Teaching poetry is preferably suitable for a classroom to improve one's language. Its peculiar structure and its features of the poem become favourite tool for language teachers. The interesting thing in reading poetry is an unusual way of ordering words, its imaginative meanings, and the contribution of musical words helps the readers to improve their language.

Through teaching literature especially poetry, the learners have a powerful motivation. When the reader is thorough with any poem or incident in the poem, they will be provoked to utter the standard words in their communication. By by-hearting the great writers, the students also inculcate the dialogues, spoken by the heroes in the poem. It boosts to build their character and also to enrich their language. The main aim of the teachers is not only to teach spelling and pronunciation but also to express their ideas in a perfect manner. It is clear that the English language learners lack confidence due to lack of vocabulary in English. There are some techniques to be adopted by the teacher in the classroom which are as follows:

a. Giving information

b. Surveys

c. Question and Answer

d. Discussion

The teaching process sets up some language models which can be used in real communication. Its focal point is to train the students to use the language in speaking circumstances. It helps the students to develop the skill of speaking in all the situations.

\section{FINDINGS}

Students develop an active, interactive and reflective relationship with the text of the poem and they can respond to the text socially, emotionally, morally, physically and culturally.

The modulation of the tone is extremely important during teaching poetry. When students work on this, it automatically enhances the speaking skills. The language teacher can use English in all sort of situations. This tempts the students to give back the reply in the same sense. Language skills cultivate to speak with others and it spread their creative power.

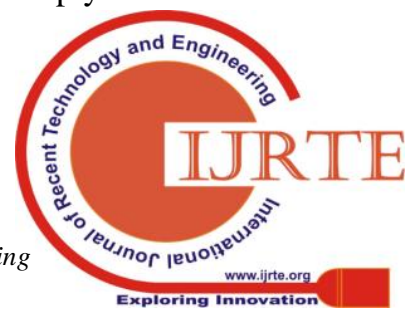


Excellent communicative skills help the students to withstand in all types of situation. The following are some of the facts to be considered.

1. The teacher has to give enough practice to each and every student.

2. One of the reasons for poor communication skills is lack of proper guidance.

3. Many students are from rural areas where the facilities such as library, book shops internet, are not available.

4. The parents of most of the students have no formal education and their educational background is mostly through Tamil medium.

5. The students do not get the proper opportunity for exposing themselves to public speaking in English.

6. The students struggle to translate their thoughts from Tamil into English.

7. The teacher has to pay more importance to slow learners.

8. The teacher needs to conduct more activities for the upliftment of the students.

9. The students have mother tongue influence whenever they try to speak in English.

10. The students are reluctant to speak in English with their friends.

11. It should be observed that teachers have to spend more time to conduct extempore and debate.

The study reveals that there is a positive impact in language teaching through poetry. Create a warm, easygoing climate in the classroom helps students get to know one another at the beginning of the year. The activities given to them help to improve the target language in the classroom. The teacher has to identify the strength and weakness of the students and behaved accordingly. The teacher should be friendly to understand the difficulties of the students. Thus, the students can share all the problems that they have to face while speaking English.

\section{SUGGESTIONS \& RESULTS DISCUSSIONS}

The aim of teaching poetry is to increase student's literary and linguistic awareness. It helps the learners to express their own creativity and images. The language also attains its ultimate through literature. Teaching a language is a difficult task. In order to make the time and effort worthwhile, English teacher should adopt an effective strategy of teaching. The students have a lot of ways to improve their communication skills. In the olden days, it was not possible but now they have very many sources to enhance the speaking skills. The students are responsible for their own improvement. The teacher encourages the students to pay attention to all situation when they conduct English as a Language. The students have to learn at least ten words in their day to day learning and keep these words on their vocabulary notebook. It promotes their speaking as well as listening skills. English is used as major language of communication in social media. Nowadays, the goal of the human is to communicate in English. First, the students learn new vocabulary and later such words become familiar. Once the words being made familiar, the learners must involve in a self dictation to conform their vocabulary acquisition. After the learners learnt the words, they must focus on the sentence structure. This is a technique that brings out the expected outcome as the learner is now familiar with the sentence. Some of the suggestions are as follows:

a. Students can be asked to write some stories and can enrich their writing skills too.

b. Students must be encouraged to seek the help of the teachers for proper guidance.

c. The parents of students must be given counseling and encouragement to motivate their children to practice at home.

d. Encouragement and support can be given to students to overcome the excessive dependence on translation.

e. Instruction has to be given for the students daily in the classroom.

f. Word game can be given in alternative classes for the enhancement of students' knowledge.

g. Teacher should use modern technology like smart classroom for the students' progress.

h. Parents should encourage their children to involve into activities.

i. The teacher can follow some new recent methods instead of chalk and talk method.

j. The teachers need to be a passive listener rather than an active speaker. Chances should be given to students the maximum.

\section{CONCLUSION}

Language should be taught as a life skill and not a subject. So it is clear that language learning is a slow process which can be catalyzed only using proper motivation and support. Teacher has to give clear cut instructions before any activity for that matter, so that the learners can get involved without much hesitation. The class should be interactive. Consequently, the language class becomes exciting at the same time it reciprocates with impulsiveness and interest. In order to expand the communicative language, the students have to take the maximum effort. Students develop an active, interactive and reflective relationship with the text of the poem and they can respond to the text socially, emotionally, morally, physically and culturally. The modulation of the tone is extremely important during teaching poetry. When students work on this, it automatically enhances the speaking skills. Language skills cultivate speaking with others thereby boost their creative power. Excellent communicative skills help the students to withstand in all sorts of situation. 
Teachers should help learners input and then comprehend it through activities. In today's highly informational and technological world, it is important to have good communication skills or presentation skills which are the need of the hour and the basic requirement of any organization as well. Good language skills are key to success in life, work and relationships. The important thing is the interest of the students. Literature is a tool for developing the written skills of the students. It also serves as a window opening to the culture of the target language. A student who is efficient and fluent in English, can excel anywhere in this competitive world.

\section{REFERENCES}

1. A Delbio, Dr. M. Ilankumaran, "Theories, Techniques, Methods and Approaches of Second Language Acquisition: A Psychological Perspective” International Journal of Engineering and Technology (IJET) (Scopus 2227-524X

2. Delbio, Dr. M. Ilankumaran, "Second Language Acquisition Through Neurolinguistic Programing: A Psychoanalytic Approach" International Journal of Engineering and Technology (IJET) (Scopus Indexed), vol.7 no 4.36, Nov. 2018, pp. 624-629, ISSN: 2227-524X

3. Delbio, Dr. M. Ilankumaran. "Process and Techniques to Improve Memory Power in Second Language Aquisition", Literatures in English for Cross Cultural Communication, Annammal Publications, Nov. 2018, pp. 189-196, ISBN: 978-81-923842-5-2

4. Delbio, Dr. R. Abilasha, Dr. M. Ilankumaran, "Second Language Acquisition and Mother Tongue Influence of English Language Learners - A Psycho Analytic Approach" International Journal of Engineering and Technology (IJET) (Scopus Indexed), vol.7 no 4.36, Nov. 2018, pp. 497-500, ISSN: 2227-524X

5. Antony. Teaching of English. Chennai. Kavyamala Publishers, 188, 2012.

6. Bright, C. Technology of Teaching English. Chennai: PDR Publishers, 2005,1-5.

7. Brumfit, C.J. Language and Literature Teaching: From Practice to Principle. Oxford: Pergamon, 1985.

8. Carter, R, Walker, R and Brumfit, C.J. Literature and the learner: Methodological Approaches (ELT Documents 130) London: Modern English Publications and The British Council, 1989.

9. Chireev, Andreea Irina. "Developing Speaking Skills in the Secondary English classroom", English Teaching: Practice and critique, vol5,no.3,2006,pp.127-136.

10. Collie, J. and S. Slater. 1990. Literature in the Language Classroom: A Resource Book of Ideas and Activities. Cambridge: CUP.

11. Delbio A, Dr. M. Ilankumaran, 'Pedagogical Approach and Strategies of English Language Teaching through Global Literature' International Journal of English Language and Literature in Humanities (IJELLH) with IF 5.7, vol.6 no.12, Dec. 2018, pp.52-59, ISSN-2321-7065 (Online)

12. Dr. M. Ilankumaran, P. Deepa "Teaching Literature Enhances Communication Skills - A Study with Special Emphasis on Poetry" International Journal of Engineering and Technology (IJET) (Scopus Indexed), vol.7 no3.6, July, 2018, pp. 187-191, ISSN: 2227-524X

13. Dr. R. Abilasha, Dr. M. Ilankumaran, 'Developing Communication Skills of Students - An Analysis on Pragmatic Performance', International Journal on Studies in English Language and Literature (IJSELL) with IF Indexed), vol.7 no3.6, July, 2018, pp. 192-197, ISSN:

3.537, Volume 6, Issue 7, July, 2018, PP 26-31, ISSN: 2347-3126 (Print) \& ISSN: 2347-3134 (Online)

14. Dr. R. Abilasha, Dr. M. Ilankumaran, 'Psychological Factors Permeating Global Literature - An Overview International Journal of English Language and Literature in Humanities (IJELLH) with IF 5.7, vol.6 no.12, Dec. 2018, pp.8-16, ISSN-2321-7065 (Online)

15. Dr. R. Abilasha, Dr. M. Ilankumaran, "Business English: The Quintessence of the Corporate World" International Journal of Engineering and Technology (IJET) (Scopus Indexed), vol.7 no 4.36, Nov. 2018, pp. 608-612, ISSN: 2227-524X

16. Dr. R. Abilasha, Dr. M. Ilankumaran, "English Language Teaching: Challenges and Strategies from the Indian Perspective" International Journal of Engineering and Technology (IJET) (Scopus Indexed), vol.7 no3.6, July, 2018, pp. 202-205, ISSN: 2227-524X

17. Dr. R. Abilasha, Dr. M. Ilankumaran, "The Role of Media in Enhancing Communicative Competence of the Learners at Tertiary Level - An Analytical Study" International Journal of Engineering and Technology (IJET) (Scopus Indexed), vol.7 no 4.36, Nov. 2018, pp. 655-659, ISSN: 2227-524X

18. Dr. R. Abilasha, Dr. M. Ilankumaran. "Content Based Instruction: A Tool to Develop Communication Skills", Literatures in English for Cross Cultural Communication, Annammal Publications, Nov. 2018, pp. 175-182, ISBN: 978-81-923842-5-2

19. Freeman. E., and Foster. W. "Poetry in General Practice Education: Perceptions of Learners”. Family Practice. 25, (2008): 294-303. Print.

20. Gosh, R.N, Sastri. H.N.L., and Das.B.K. eds. "Introductions to English Language Teaching": Reading Horizons. 34, (2009): 87-96. Print.

21. Ilankumaran $\mathrm{M}$, Venugopalan $\mathrm{P}$, "Communication Skills in English Through Developmental Speaking”.Contemporary Reviewed, vol.3, no.2, 2012.

22. Issac, Alfred. I. Technology of Teaching English Paper. 3rd ed. Nagercoil: Vijaya Publishers. 2012. 156-193,243. Print.

23. K. JeyaGowri, Dr. M. Ilankumaran, 'World Literature as a Tool for Learning English in the Classroom Environment' International Journal of English Language and Literature in Humanities (IJELLH) with IF 5.7, vol.6 no.12, Dec. 2018, pp.89-96, ISSN-2321-7065 (Online)

24. K. JeyaGowri, Dr. M. Ilankumaran, "Application of Theories, Techniques, Methods and Approaches to Develop Second Language Skills - A Study based on Transition from Schooling to College" International Journal of Engineering and Technology (IJET) (Scopus Indexed), vol.7 no3.6, July, 2018, pp. 210-215, ISSN: 2227-524X

25. K. JeyaGowri, Dr. M. Ilankumaran, "The Role of Students in Transition from School to College: Different Challenges in ELT" International Journal of Engineering and Technology (IJET) (Scopus Indexed), vol.7 no 4.36, Nov. 2018, pp. 630-635, ISSN: 2227-524X

26. K. JeyaGowri, Dr. M. Ilankumaran. "The Struggling ESL Learners: A Study on Difficulties in Language Learning at Tertiary Level", Literatures in English for Cross Cultural Communication, Annammal Publications, Nov. 2018, pp. 197-205, ISBN: 978-81-923842-5-2

27. K. JeyaGowri, Dr. R. Abilasha, Dr. M. Ilankumaran, "Enriching Cognizance at the Tertiary Level Students During Transition" International Journal of Engineering and Technology (IJET) (Scopus Indexed), vol.7 no 4.36, Nov. 2018, pp. 665-668, ISSN: 2227-524X 
28. Kershner, R. "Developing students' teachers understanding of strategies for teaching children": Education Today, 2000, 4(50): 31-39. Print.

29. Kohli, A. L. Techniques of Teaching English. New Delhi; DhanpatRai Publishing Company Private Limited, 1970. Print.

30. Krishnaswamy, N., and Lalitha, Krishnaswamy. Methods of Teaching English. NewDelhi: Macmillan, 2006, $167-$ 177. Print.

31. Mittal, Reena "Teaching English through Poetry:A powerful medium for learning second language"Journal of Humanities and social science.vol.19,pp-21-23.

32. Mittal, Reena, Teaching English through Poetry: A Powerful medium for Learning Second Language, Journal of Humanities and social science. Vol 19.

33. P. Deepa, Dr. M. Ilankumaran, "Teaching Poetry Enhances Speaking Skills - An Analysis based on Select Poems" International Journal of Engineering and Technology (IJET) (Scopus Indexed), vol.7 no 4.36, Nov. 2018, pp. 619-623, ISSN: 2227-524X

34. Patki,L.AdarshSachin.'Development of Speaking skills through Literature"confluence,2013,pp.22-23.

35. Richard,C. "Literature and English Language Teaching and Learning: A symbiotic Relationship."Canadian center of Science and Education.vol.7, no.3, 2014. pp. 85-90.

36. Ronald Carter, and Michael, N. Teaching Literature, Longman Group UK. Second language vol.19,2014,pp.21-23.

37. S. Sreena, Dr. M. Ilankumaran, 'The Role of Teachers in Developing Second Language Acquisition' International Journal of Research in Humanities, Arts and Science with IF 2.135, vol.2 no.9, April, 2018, pp. 40-43, EISSN: 2456-5571

38. S. Sreena, Dr. M. Ilankumaran, "Developing Productive Skills through Receptive Skills - A Cognitive Approach" International Journal of Engineering and Technology (IJET) (Scopus Indexed), vol.7 no 4.36, Nov. 2018, pp. 669-673, ISSN: 2227-524X

39. S. Sreena, Dr. M. Ilankumaran, "Developmental Speaking as A Strategy to Enhance Communicative Skills - A Cognitive Based Approach" International Journal of Engineering and Technology (IJET) (Scopus Indexed), vol.7 no 4.36, Nov. 2018, pp. 613-618, ISSN: 2227-524X

40. S. Sreena, Dr. M. Ilankumaran. "Developing Communication Skills using Developmental Speakng as a Technique", Literatures in English for Cross Cultural Communication, Annammal Publications, Nov. 2018, pp. 254-261, ISBN: 978-81-923842-5-2

41. Stange. V, Terrence. "Poetry Proves to be Positive in the Primary Grades". Reading Horizons. 48, (2008): 101211.Print.

42. Stephen, Elting and Firkins, Arthur "Dramatizing poetry in the second language University Press. 1996. 